\section{Determination of the frequency of connexin 26 mutations in inherited sensorineural deafness and carrier rates in the Tunisian population using DGGE}

EDITOR-Congenital deafness occurs in approximately 1 in 1000 live births and at least $50 \%$ of these cases are hereditary. ${ }^{1}$ Among the prelingual genetic forms of deafness, the autosomal recessive forms (DFNB) are frequent $(80 \%$ of the cases) and in most cases are sensorineural and severe. ${ }^{1}$ Twenty eight loci that cause autosomal recessive nonsyndromic hearing loss (ARNSHL) have been identified (http://dnalab-www.uia.ac.be./dnalab/hhh/index.html).

The first locus defined for recessive deafness (DFNB1) is linked to chromosome 13q12-13 and was identified by homozygosity mapping in two large consanguineous families from Tunisia. ${ }^{2}$ This initial report was followed by the identification of other consanguineous families of different ethnic origins which were linked to the DFNB1 locus and of several non-consanguineous white families in which the ARNSHL phenotype cosegregated with markers from chromosome 13q12-13..$^{3-6}$ Mutations in connexin26 (Cx26), a gene that encodes gap junction protein beta-2 (GJB-2), have been shown to result in autosomal recessive (DFNB1) and dominant (DFNA3) non-syndromic sensorineural deafness. ${ }^{7}$ Mutations in the $C \times 26$ gene have been found to be the most common cause of autosomal recessive deafness and the most frequently observed mutation is $35 \mathrm{delG}^{8-12}$

The high prevalence of $C \times 26$ mutations and their importance as a cause of ARNSHL have prompted the development of several different mutation detection assays to screen the single $C \times 26$ coding exon. ${ }^{13-16} \mathrm{~A}$ rapid method to detect mutations in the $G \mathcal{F B} 2$ gene would be very useful in the diagnosis of deafness and in the assessment of carrier status. In this paper, we have developed a denaturing gradient gel electrophoresis (DGGE) method for screening sequence variation in the coding region of $C \times 26$. This technique was used to determine the carrier frequency of the 35 delG mutation in 236 unrelated, unaffected Tunisians and to estimate the prevalence of $C \times 26$ mutations in 70 families affected by ARNSHL with various degrees of hearing loss (42 profound, 20 severe, five moderate, three mild). All families were unrelated and originated from different regions of Tunisia.

Two segments of $C \times 26$ gene DNA, each containing a single uniform melting domain, were selected using the computer program MELT94 (http://web.mit.edu/osp/ www/melt.html). The segments are defined by the PCR primers Cx175-F/Pso-Cx478-R (TTC CAG AGC AAA CCG CCC AG/psoralenTA-TCC GGT AGG CCA CGT GCA TG) and Cx462-F/Cx780-R (CAG CGC TCC TAG TGG CCA TG/psoralenTA-AGA CAC TGC AAT CAT GAA CA). PCR amplification was carried out under standard conditions. Temperature cycling for amplification was as follows: $94^{\circ} \mathrm{C}$ for 40 seconds, $64^{\circ} \mathrm{C}$ for 30 seconds, and $72^{\circ} \mathrm{C}$ for 45 seconds for 35 cycles. PCR products of affected and control subjects with and without PCR product of wild type DNA were denatured at $95^{\circ} \mathrm{C}$ for three minutes and cooled progressively for 30 minutes to $37^{\circ} \mathrm{C}$. For psoralen crosslinking, samples were placed on an
ELISA plate and exposed to UV light (365 nm) for 18 minutes. Under these conditions, $70-90 \%$ of the strands in the reannealed fragments became crosslinked. After crosslinking, the PCR samples were subjected to electrophoresis at $97 \mathrm{~V}$ on a $6 \%$ polyacrylamide gel with a linear $30-80 \%$ denaturant gradient parallel to the direction of electrophoresis. The appropriate running time for DGGE was 16 hours. The gels were stained for 10 minutes with ethidium bromide $(1 \mu \mathrm{g} / \mathrm{ml})$ and photographed with a UV transilluminator. PCR products that showed shifts after DGGE analysis were sequenced on an ABI 377 Perkin Elmer sequencer. The sequencing primers were $\mathrm{Cx} 26 \mathrm{~A}-\mathrm{U} /$ Cx26A-L. ${ }^{13}$ The use of a broad gradient of $30-80 \%$ denaturant permits simultaneous analysis of a large number of mutations. Psoralen oligonucleotide conjugates provide a good alternative to the commonly used GC tailed oligonucleotides, offering the advantage of lack of strand separation of high denaturant concentration.

DGGE analysis showed two different patterns in affected subjects (fig 1). To confirm the presence and identity of the mutations, PCR product which showed shifts after DGGE analysis were sequenced and the results were confirmed by sequence analysis. In fact, two mutations were

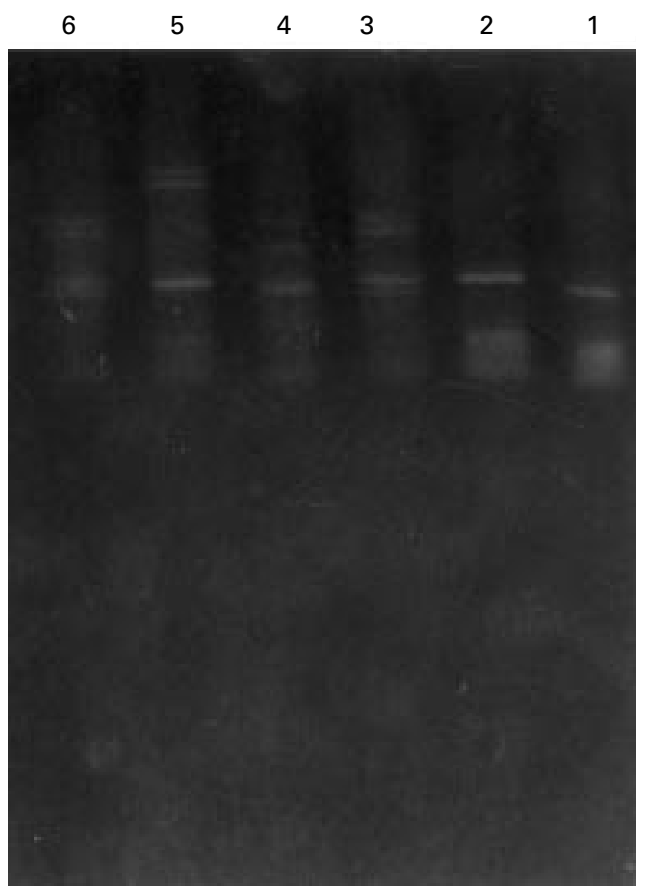

Figure 1 Parallel denaturing gradient gel electrophoresis of fragment 1 of the connexin26 gene. (1) Crosslinked wild type (WT), (2) crosslinked mutant type (MT) (homozygous 35delG), (3) crosslinked WT $\times M T$ (homozygous 35delG), (4) crosslinked WT $\times$ MT (homozygous E47X), (5) crosslinked MT (homozygous delG35) $\times M T$ (homozygous E47X), (6) crosslinked MT (heterozygous 35delG). The crosslinked samples of WT and MT gave single bands with nearly identical retardation level. For the crosslinked WT $\times$ MT (35delG), the typical heteroduplex-homoduplex doublet can be seen and the two individual heteroduplex bands and the two homoduplex bands are resolved. The crosslinked WT $\times M T(E 47 X)$ sample exhibited a band with the same retardation level, consisting of the two expected types of unresolved homoduplex molecules and a more retarded doublet of bands, consisting of the two expected types of heteroduplex molecules. The crosslinked MT (35delG) $\times M T(E 47 X)$ showed a different pattern in comparison with that obtained with the crosslinked WT $\times M T(35 \mathrm{del} G)$ or the crosslinked WT $\times M T(E 47 X)$. 
detected (35delG and E47X). Homozygous 35delG and E47X mutations were found in 10 and one families, respectively, and we also found E47X in trans with 35delG in another family. A heterozygous $35 \mathrm{delG}$ mutation was detected in three controls. Previous indications that the DFNB1 locus might be a relatively important contributor to recessive prelingual deafness in the Tunisian population ${ }^{3}$ were confirmed here; Cx26 mutations were found in 12 $(17 \%)$ of the 70 families. The prevalence of the $C \times 26$ mutation has been shown to vary from $13 \%$ in the Japanese deaf population ${ }^{18}$ to $49 \%$ in European populations. ${ }^{10}{ }^{17}$ In our study, the most common Cx26 mutation found was $35 \mathrm{delG}$. Analysis of 236 unrelated Tunisian people from the general population showed three $35 \mathrm{delG}$ heterozygotes, which gave a carrier prevalence of $1.3 \%$. Carrier frequencies for $35 \mathrm{delG}$ have been shown to vary from $0.73 \%$ in the Ashkenazi Jewish population (where $167 \mathrm{delT}$ is seen at a frequency of about $4 \%$ ) to $4 \%$ in subjects from Italy. ${ }^{10}{ }^{12}$

Recent studies have shown that hearing loss may be mild, moderate, severe, or profound in patients with $C \times 26 .{ }^{17}{ }^{19}$ In our study, all patients with $C \times 26$ mutations have profound bilateral deafness, except in one family where patients were homozygous for the $35 \mathrm{delG}$ mutation and exhibited intrafamilial variation in the severity of deafness. This suggests the existence of other factors moderating the expression of the mutant gene.

In conclusion, we have developed a DGGE method for the detection of carriers and affected subjects in deaf families carrying $C \times 26$ mutations. Our study showed that the prevalence of mutations in the $C x 26$ gene was relatively high in the Tunisian population and the most common Cx26 mutation found was $35 \mathrm{delG}$.

We are grateful to the family members for their participation in this study. We thank Jamel Chelly, Cherif Beljord for technical help with the DGGE, and Dominique Weil for critical reading of the manuscript. This work was supported by "Secrétariat d'Etat à la Recherche Scientifique et à la Technologie" (Tunisia), AFM (France), INSERM-DGRST, and CNRS-PICS (France-Tunisia).

SABER MASMOUDI* AMEL ELGAIED-BOULILA* ILYES KASSAB十 SAIDA BEN ARAB ${ }^{\star}$ STEPHANE BLANCHARD JA-EL BOUZOUITA $\dagger$ MOHAMED DRIRA AICHA KASSAB $†$

SLAH HACHICHA CHRISTINE PETIT $\ddagger$

*Laboratoire d'Immunologie et de Biologie Moléculaire, Faculté de Médecine, 3029 Sfax, Tunisia

†Service d'ORL, CHU F Bourguiba, Monastir, Tunisia

$\ddagger$ Unité de Génétique des Déficits Sensoriels, CNRS URA 1968, Institut

Pasteur, 25 rue du Dr Roux, 75724 Paris cedex 15, France

\Service d'ORL, CHU H Bourguiba, 3018 Sfax, Tunisia

\Service d'ORL, CHU Rabta, Tunis, Tunisia

Correspondence to: Dr Ayadi, hammadi.ayadi@fmsf.rnu.tn
1 Morton NE. Genetic epidemiology of hearing impairment. Ann NY Acad Sci 1991;630:16-31.

2 Guilford P, Ben Arab S, Blanchard S, Levilliers J, Weissenbach J, Belkahia A, Petit C. A non-syndromic form of neurosensory, recessive deafness maps to the pericentromeric region of chromosome 13q. Nat Genet 1994;6:24-8.

3 Boulila-Elgaied A, Masmoudi S, Drira M, Gouia M, Chaib H, Petit C, Ayadi $\mathrm{H}$. Contribution of DFNB1 and DFNB2 loci to neurosensory deafness in affected Tunisian families. Archs Inst Pasteur Tunis 1997;74:5-8.

4 Brown KA, Janjua AH, Karbani G, Parry G, Noble A, Crokford G, Bishop DT, Newton VE, Markham AF, Mueller RF. Linkage studies of non-syndromic recessive deafness (NSRD) in a family originating from the Mirpur region of Pakistan maps DFNB1 centromeric to D13S175. Hum Mol Genet 1996;5:169-73.

5 Maw MA, Allen-Powell DR, Goody RG, Stewart LA, Nancarrow DG, Hayward NK, McKinlay Gardner RJ. The contribution of the DFNB1 locus to neurosensory deafness in a Caucasian population. Am f Hum Genet 1995; 37:629-35.

6 Scott DA, Carmi R, Elbedour K, Yosefsberg S, Stone EM, Sheffield VC. Non-syndromic autosomal recessive deafness is linked to the DFNB1 locus in a large inbred bedouin family from Israel. Am 7 Hum Genet in a large in $1995 ; 59: 965-8$

7 Denoyelle F, Lina-Granade G, Plauchi H, Bruzzone R, Chaib H, Lévi-Acobas F, Weil D, Petit C. Connexin 26 gene linked to a dominant deafness. Nature 1998;393:319-20.

8 Denoyelle F, Weil D, Maw M, Wilcox SA, Lench NJ, Allen-Powell DR, Osborn AH, Dahl HHM, Middleton A, Houseman MJ, Dodé C, Marlin S, Boulila-Elgaied A, Grati M, Ayadi H, Ben Arab S, Bitoun P, Lina-Granade G, Codet J, Mustapha M, Loiselet J, El-Zir E, Aubois A, Joannard A, Levilliers J, Garabédian EN, Mueller RF, Gardner RJM, Petit C. Prelingual deafness: high prevalence of a $35 \mathrm{delG}$ mutation in the connexin 26 gene. Hum Mol Genet 1997;6:2173-7.

9 Zelante L, Gasparini L, Estivill X, Melchionda S, D'Agruma L, Govea N, Milà $M$, Della Monica $M$, Lutfi J, Shohat $M$, Mansfield E, Delgrosso K, Rappaport E, Surrey S, Fortina P. Connexin 26 mutations associated with the most common form of non-syndromic neurosensory autosomal recessive deafness (DFNB1) in Mediterraneans. Hum Mol Genet 1997;6: 1605-9.

10 Estivill X, Fortina P, Surrey S, Robionet R, Melchionda S, D'Agruma L, Mansfield E, Rappaport E, Govea N, Milà M, Zelante L, Gasparini P. Connexin-26 mutations in sporadic and inherited sensorineural deafness. Lancet 1998;351:394-8.

11 Green GE, Scott DA, McDonald JM, Woodworth GG, Sheffield VC, Smith $\mathrm{RJH}$. Carrier rates in the midwestern united states for $G \mathcal{F B 2}$ mutations causing inherited deafness. $\mathcal{F A M A}$ 1999;281:2211-16.

12 Morell RJ, Jeff Kim H, Hood LJ, Goforth L, Friderici K, Fisher R, Van Camp G, Berlin CI, Oddoux C, Ostrer H, Keats B, Friedman TB. Mutations in the connexin 26 gene (GFB2) among Ashkenazi Jews with nonsyndromic recessive deafness. N Engl f Med 1998;339:1500-5.

13 Kelley PM, Harris DJ, Comer BC, Askew JW, Fowler T, Smith SD, Kimberling WJ. Novel mutations in the connexin 26 gene (GJB2) that cause autosomal recessive (DFNB1) hearing loss. Am f Hum Genet 1998;62:792-9.

14 Rabionet R, Estivill X. Allele specific oligonucleotide analysis of the common deafness mutation $35 \mathrm{delG}$ in the connexin 26 (GJB2) gene. $\mathcal{F}$ Med Genet 1999;36:260-1.

15 Scott DA, Kraft ML, Carmi R, Ramesh A, Elbedour K, Ramesh A, Yairi Y, Srikumari Srisailapathy CR, Rosengren SS, Mrkham AF, Mueller RF, Lench NJ, Van Camp G, Smith RJH, Sheffield VC. Identification of mutations in the connexin 26 gene that cause autosomal recessive nonsyndromic hearing loss. Hum Mutat 1998;11:387-94.

16 Storm K, Willocx S, Flothmann K, Van Camp G. Determination of the carrier frequency of the common GJB2 (connexin-26) 35 delG mutation in the rier frequency of the common GJB2 (connexin-26) 35delG mutation in the
Belgian population using an easy and reliable screening method. Hum Belgian population using
Mutat 1999;14:263-6.

17 Denoyelle F, Marlin S, Weil D, Moatti L, Chauvin P, Garabéian EN, Petit C. Clinical features of the prevalent form of childhood deafness, $D F N B 1$, due to a connexin-26 gene defect: implications for genetic counselling. Lancet 1999;353:1298-303.

18 Kudo T, Kure S, Matsubara Y, Ikeda K, Oshima T, Watanabe K, Kawase T, Takasaka T, Narisawa K. Identification of a novel common mutation in the connexin 26 gene (GfB2) among Japanese patients with childhood connexin 26 gene (GfB2) among Jap

19 Cohn ES, Kelley PM, Fowler TW, Gorga MP, Lefkowitz DM, Kuehn HJ, Schaefer GB, Gobar LS, Hahn FJ, Harris DJ, Kimberling WJ. Clinical studies of families with hearing loss attributable to mutations in the connexin 26 gene. Pediatrics 1999;103:546-50. 